\title{
Peran Orang Tua dalam Mengontrol Penggunaan Gadget pada Anak Usia 11 Tahun
}

\author{
Shella Tasya Hidayatuladkia ${ }^{1}$, Mohammad Kanzunnudin², Sekar Dwi Ardianti ${ }^{3}$
}

1,2,3 Pendidikan Guru Sekolah Dasar, Universitas Muria Kudus, Kudus, Indonesia

\section{A R T I C L E I N F O}

Article history:

Received August 07, 2021

Revised August 08, 2021

Accepted September 30, 2021

Available online October 25, 2021

Kata Kunci:

Orang tua, Gadget, Anak Usia 11 Tahun

Keywords:

Role of Parents, Gadgets, and

Children 11 years

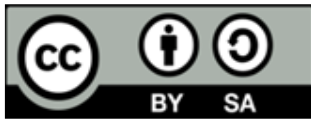

This is an open access article under the CC BY-SA license.

Copyright $(2021$ by Author. Published by Universitas Pendidikan Ganesho.

\begin{abstract}
A B S T R A K
Berkembangnya ilmu pengetahuan dan teknologi membuat pengguna gadget tidak hanya berasal dari kalangan orang dewasa namun telah sampai pada anak-anak. Penggunaan gadget khusunya pada anak membawa dampak positif dan negatif, sehingga sangat diperlukan peran orang tua dalam mengawasi anak saat menggunakan gadget. Tujuan penelitian ini untuk mengetahui peran orang tua dalam mengontrol penggunaan gadget pada anak dan mengetahui dampak penggunaan gadget pada anak usia 11 tahun. Penelitian ini menggunakan pendekatan kualitatif dengan jenis penelitian deskriptif dan studi kasus. Yang menjadi subjek dalam penelitian ini adalah orang tua dan anak usia 11 tahun. Data diperoleh melalui wawancara dengan informan, observasi, dan dokumentasi. Teknik analisis data yang digunakan adalah penyederhanaan data, penyajian data, dan penarikan kesimpulan. Hasil penelitian menunjukkan bahwa peran orang tua dalam mengontrol atau mengawasi penggunaan gadget pada anak usia 11 tahun yakni dengan membatasi waktu penggunaan gadget, selektif dalam memilihkan aplikasi gadget pada anak, menemani anak dalam pengunaan gadget, melatih tanggung jawab anak, berinteraksi sosial. Dampak positif penggunaan gadget yakni dapat menambah pengetahuan, memperluas jaringan persahabatan, dan mempermudah komunikasi, sedangkan dampak negatif penggunaan gadget mengabaikan perintah orang tua, kecanduan, serta konsentrasi belajar yang menurun. Adanya penelitian ini hendaknya orang tua lebih mengawasi anak dalam penggunaan gadget dengan memberikan aturan atau batasan waktu agar anak dalam masa pandemi ini tetap belajar di rumah dengan baik dengan hasil belajar yang bagus. Orang tua senantiasa mendampingi anak agar anak terhindar dari kecanduan gadget.
\end{abstract}

\section{A B S T R A C T}

The development of science and technology makes gadget users not only come from among adults but has reached children. The use of gadgets, especially in children, has positive and negative impacts, so the role of parents is very much needed in supervising children when using gadgets. The purpose of this study was to determine the role of parents in controlling the use of gadgets in children and to determine the impact of using gadgets on children aged 11 years. This research uses a qualitative approach with descriptive research and case studies. The subjects in this study were parents and children aged 11 years. Data obtained through interviews with informants, observation and documentation. The data analysis technique used is data simplification, data presentation and conclusion drawing. The results showed that the role of parents in controlling or supervising the use of gadgets in children aged 11 years was by limiting the time of using gadgets, being selective in choosing gadget applications for children, accompanying children in using gadgets, training children's responsibility, and interacting socially. The positive impact of using gadgets is that it can increase knowledge, expand friendship networks, and facilitate communication, while the negative impacts of using gadgets are ignoring parental orders, addiction, and decreased learning concentration. With this research, parents should supervise children more in using gadgets by providing rules or time limits so that children in this pandemic period continue to study at home well with good learning outcomes. Parents always accompany their children so that children avoid being addicted to gadgets. 


\section{PENDAHULUAN}

Berkembangnya ilmu pengetahuan dan teknologi membawa perubahan hampir pada seluruh tatanan kehidupan manusia. Di era globalisasi ini kemajuan media informasi dan teknologi sudah di rasakan hampir seluruh lapisan masyarakat (Dahlia, Safiah, \& Z., 2017; E. Dewi, 2019). Teknologi adalah benda-benda atau alat-alat yang diciptakan oleh menusia untuk membantu dan mempermudah pekerjaan manusia dalam melakukan beberapa hal (Husaini, 2019; Saputri \& Pambudi, 2018). Semakin berkembangnya teknologi dan informasi membuat semua orang semakin mudah mengakses segala macam informasi (Azizul, Riski, Fitriyani, \& Sari, 2020; Lestari, 2018). Salah satu wujud dari perkembangan teknologi adalah dengan adanya gadget (E. Dewi, 2019; Patricia, 2020). Gadget adalah perangkat elektronik kecil yang memiliki fungsi khusus. Gadget merupakan media yang berkembang di era modern yang dapat mempermudah kegiatan komunikasi manusia (Arwansyah \& Wahyuni, 2020; Hudaya, 2018). Gadget sudah tersedia di mana-mana baik dalam bentuk laptop, computer, smartphone, televisi, radio, game dan lain sebaginya (Novitasari \& Khotimah, 2016; Witarsa, 2018). Di Indonesia gadget berkembang sangat pesat. Bahkan menjadi salah satu negara dengan Facebook, Twitter, dan whastapp terbesar di dunia yang penggunanya masing-masing mencapai 52 juta. Berbagai fitur-fitur dan aplikasi yang menarik, bervariasi, interaktif dan fleksibel pada gadget memudahkan manusia untuk memenuhi kebutuhan hidupnya dengan sangat cepat dan mudah.

Teknologi telah membantu dan mempengaruhi semua kalangan baik itu orang dewasa, remaja, bahkan anak-anak. Salah satunya adalah anak-anak SD yang berusia antara 6-12 tahun. Usia 6-12 tahun juga dikenal sebagai masa sekolah, anak - anak telah mampu menerima pendidikan formal dan menyerap berbagai hal yang ada di lingkungannya (Kusumantara, Santyadiputra, \& Sugihartini, 2017; Murni, 2017). Pada tahap usia 7 - 11 tahun anak sudah dapat melakukan berbagai macam tugas yang konkret. Anak mulai mengembangkan tiga macam operasi berpikir yaitu identifikasi (mengenali sesuatu), negasi (mengingkari sesuatu), dan reprokasi (mencari hubungan timbal balik antara beberapa hal. Anak usia 11 tahun adalah anak yang mempunyai rasa ingin tahu dalam menyerap berbagai hal yang ada di lingkungannya, mampu melakukan operasi dan penalaran logis sehingga sudah siap dalam menerima pendidikan formal dan sedang dalam tahap belajar dari berbagai hal mulai dari mengenali sesuatu, mencari hubungan timbal balik, serta dalam perkembangan perilaku sosial anak membandingkan sesuatu dengan aturan-aturan (Chusna, 2017b; Kumala, Ani Margawati, \& Rahadiyanti, 2019; Rini, Pratiwi, \& Ahsin, 2021). Teknologi berupa gadget sangat mudah menarik perhatian dan minat anak-anak. Semakin berkembangnya teknologi menjadi salah satu faktor meningkatnya persetase anak menggunakan gadget. Berdasarkan penelitian terdahulu diketahui bahwa terjadi peningkatan penggunaan media dan gadget pada anak yaitu 38\% pada tahun 2011 dan meningkat menjadi 72\% pada tahun 2013 (Nurhalipah, Yustiana, Saeni, \& Muslih, 2020). Gadget memiliki banyaknya fitur-fitur seperti games dan gadget ini mudah untuk digunakan. Namun, dengan keberadaan gadget juga bisa digunakan sebagai alat atau media pembelajaran yang sangat efektif (Alia \& Irwansyah, 2018; Husaini \& Lampung, 2014). Jadi, dapat dikatakan bahwa penggunaan teknologi gadget pada saat ini memiliki dampak positif dan negatif bagi anak.

Dampak positif penggunaan gadget sebagai berikut. (1) menambah pengetahuan, dengan menggunakan gadget yang berteknologi canggih, anak-anak dengan mudah dan cepat untuk mendapatkan informasi mengenai tugasnya disekolah (Damayanti, Ahmad, \& Bara, 2020; Nurhalipah et al., 2020), (2) memperluas jaringan persahabatan karena dapat dengan mudah dan cepat bergabung ke sosial media jadi kita dengan mudah berbagi bersama teman kita, (3) mempermudah komunikasi karena gadget suatu alat yang memiliki teknolgi yang canggih sehingga semua orang dapat dengan mudah berkomunikasi dengan orang lain dari seluruh penjuru dunia, dan (4) melatih kreativitas anak (Pujilestari, 2020; Rikizaputra \& Sulastri, 2020). Diharapkan dengan adanya perkembangan teknologi berupa gadget dapat meningkatkan minat serta hasil belajar siswa.

Namun yang terjadi di lapangan. penggunaan gadget pada anak-anak lebih dominan pada dampak negatifnya. Menurunnya minat belajar anak karena lebih suka bermain gadget. Anak yang kecanduan gadget menyebabkan anak menjadi pribadi yang tertutup dan suka menyendiri. Selain itu, anak bisa mengalami beberapa gangguan seperti gangguan pada kesehatan otak, kesehatan mata, kesehatan tangan, dan gangguan tidur (Anggraeni, 2019; Kumala et al., 2019). Dengan adanya gadget, anak rentan terkena paparan radiasi karena efek yang ditimbulkan ketika bermain gadget terlalu lama biasanya mengakibatkan mata berair karena kelelahan mata. Kecenderungan anak menjadi kurang kreatif lagi. Hal itu dikarenakan ketika anak diberi tugas oleh sekolah ia tinggal browsing internet untuk menyelesaikan tugas. Ancaman cyberbullying atau pelecehan di dunia maya yang biasanya terjadi melalui jejaring sosial juga termasuk dampak negatif penggunaan gadget pada anak. Penggunaan gadget secara terus menerus akan menimbulkan kecanduan pada penggunanya. Selain itu, berdasarkan observasi awal peran orang tua dalam mengontrol anak pada pengunaan gadget di lingkungan sekitar Desa Soco masih kurang karena 
orang tua tidak mengetahui dampak yang akan ditimbulkan oleh gadget. Orang tua terlalu sibuk dengan pekerjaan, sehingga kurang peka terhadap anak.

Hal itu tentu menjadi perhatian karena dampak negatif yang begitu mengkhawatirkan terlebih bagi anak-anak yang menggunakan gadget. Oleh sebab itu, peran orang tua sangat penting dalam memberikan dan melakukan pengawasan serta pengontrolan penggunaan gadget pada anak (Imron, 2017) mengemukakan hal-hal yang dilakukan orang tua untuk meminimalisir anak dari pengaruh negatif penggunaan gadget (1) mendampingi anak, (2) membuat kesepakatan waktu dalam penggunaan gadget, (3) membuat kesepakatan dalam membuka fitur-fitur yang akan dibuka, (4) modelling yang baik dari orang tua, (5) orang tua dapat menaruh gadget dengan baik, dan (7) mengajak anak untuk belajar bersama. Sebagai orang tua, sebaiknya mereka membimbing dan memantau serta memberikan pemahaman yang baik kepada anak untuk lebih selektif dalam memilih permainan (game online) yang terdapat pada gadget (Ariston \& Frahasini, 2018; Pebriana, 2017).

Dalam menanggulangi dampak negatif penggunaan gadget orang tua harus mampu mendidik dan mengarahkan anaknya sejak dini melalui sikap dan perbuatan yang sepatutnya dicontoh oleh anak anaknya. Sebuah keluarga disarankan untuk lebih memperhatikan penggunaan gadget pada anak saat dirumah dengan cara memberikan batasan waktu untuk bermain gadget pada anak saat dirumah dengan melakukan hal yang menarik seperti mengajak bermain diluar rumah, ajak anak untuk lebih banyak beraktivitas (olahraga, bermain musik, dll), dan bersosialisasi dengan teman sebayanya. Peran orang tua dalam mengawasi penggunaan gadget untuk anak-anak SD/sederajat adalah dilakukan melalui pengawasan waktu dan pengawasan akses yang digunakan oleh anak-anak melalui gadget, tingkat SMP/sederajat adalah masih dikontrol hanya tidak seperti anak sekolah dasar, saat di sekolah menengah/pendidikan yang setara dengan mengawasi kegiatan anak-anak dalam menggunakan gadget yang tidak menahan.

Hal ini sejalan dengan peneliatian yang menyebutkan bahwa peran orang tua dalam mengawasi penggunaan gadget pada anak adalah harus bersikap tegas dan tidak boleh memanjakan anaknya yang masih usia dini untuk menggunakan gadget secara terus menerus karena lebih banyak dampak negatif yang timbul apabila seorang anak di bawah umur telah diberikan gadget (Putriana, Pratiwi, \& Wasliah, 2019; Sahriana, 2019). Penelitian yang sama juga menunjukkan hasil bahwa kegiatan pendampingan dan bimbingan orang tua terhadap anak saat menggunakan gawai harus selalu diterapkan agar anak sudah terlanjur pengguna berat gawai berangsur-angsur dapat mengurangi aktivitasnya dalam penggunaan gawai (Karwati, Kurniawan, \& Anggraeni, 2020). Peran orang tua dalam kegiatan pembelajaran dengan menggunakan gadget sangatlah penting, yaitu orang tua membantu menjelaskan dan membimbing anak ketika sedang belajar (Asmuni., 2020).

Berdasarkan jabaran-jabaran tersebut memberikan gambaran tentang dampak positif dan negatif dari gadget serta pentingnya peranan orang tua dalam mengawasi penggunaan gadget pada anak. Sehingga dilakukan penelitian ini untuk mengetahui peran orang tua dalam mengontrol penggunaan gadget pada anak dan mengetahui dampak penggunaan gadget pada anak usia 11 tahun. Dengan mengetahui peran orang tua dalam mengawasi penggunaan gadget pada anak akan membatu orang tua mengtasi dampak negative yang ditimbulkan oleh gadget. Selain itu dapat mempereat hubungan antara anak dan orang tua karena terjadi komunikasi yang bersifat positif. Penggunaan gadget pada anak dapat dimanfaatkan sebagai sarana belajar yang berdampak terhadap meningkatkan minat dan hasil belajar pada anak.

\section{METODE}

Penelitian ini menggunakan pendekatan kualitatif dengan jenis penelitian deskriptif dan studi kasus. Penelitian ini dilakukan pada bulam Mei hingga Juni 2021 di Desa Soco Kecamatan Dawe Kabupaten Kudus. Metode penelitian deskripsti kualitatif mempunyai ciri-ciri yakni menggambarkan proses dari waktu ke waktu dalam situasi yang alami tanpa rekayasa serta dapat mengungkap hubungan yang wajar antara peneliti dengan informant Nugrahani (2014). Dalam melakukan penelitian studi kasus, peneliti dapat berinteraksi terus menerus dengan data - data yang dikumpulkan Nugrahani (2014). Selain itu juga dapat menggunakan berbagai sumber bukti penelitian tentang peristiwa yang berkonteks kehidupan nyata. Yang menjadi subjek dalam penelitian ini adalah orang tua dan anak usia 11 tahun.

Penelitian ini memfokuskan pada informan berdasarkan kategori tertentu. Perbedaan kategori tersebut diharapkan dapat memberikan sumber data yang beragam sehingga dalam penelitian ini memperoleh sumber data yang kompleks. Selain itu, penelitian ini juga bertujuan agar peneliti dapat mengetahui bagaimana peran orang tua dalam mengontrol penggunaan gadget pada anak usia 11 tahun yang hasil belajarnya tinggi, sedang maupun rendah. Adapun kategorisasi informan dalam penelitian ini sebagai berikut. 


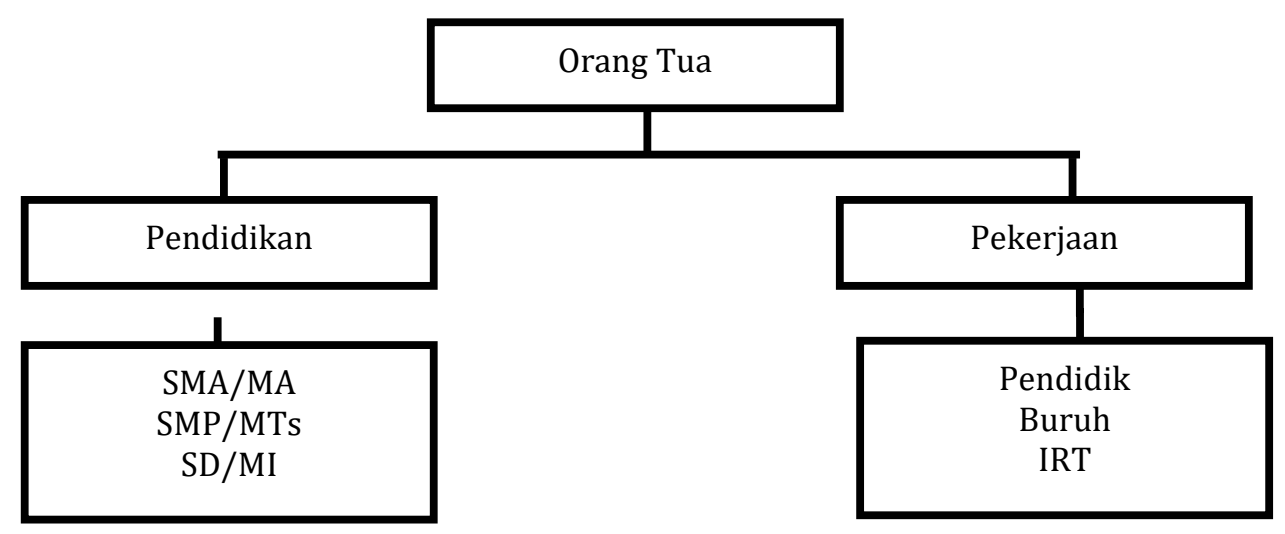

Gambar 1. Kategorisasi Orang Tua

Dalam kategori anak peneliti memilih anak usia 11 tahun karena di lingkungan penelitian yang sudah memiliki gadget dan sering berkumpul untuk bermain gadget kebanyakan anak usia 11 tahun. Maka peneliti mengambil anak usia 11 tahun untuk dijadikan sebagai informan dalam penelitian ini.

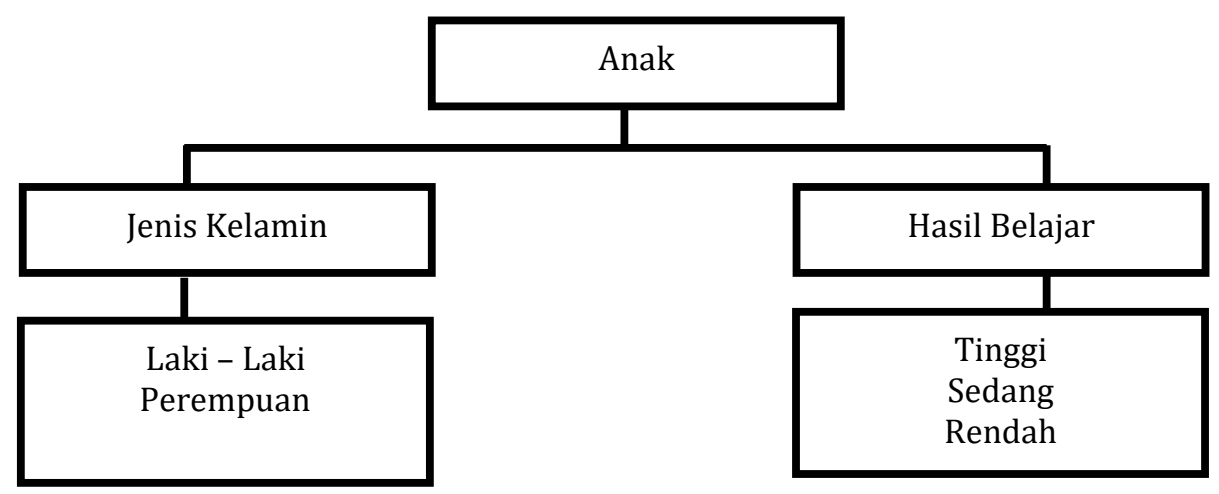

Gambar 2. Kategorisasi Anak

Teknik pengumpulan data dalam penelitian ini yakni dengan 1) Observasi, observasi dapat dilakukan secara langsung dan tidak langsung, dengan mengambil peran atau tidak berperan. Observasi ini dapat dilakukan secara formal dan informal, dengan melibatkan peneliti sebagai anggota lembaga atau kelompok masyarakat yang diteliti. 2) wawancara mendalam, wawancara terstruktur adalah wawacara yang dilakukan secara terencana dengan memersiapkan instrument penelitian berupa pertanyaanpertanyaan tertulis sedangkan wawancara tidak terstruktur adalah wawancara yang dilakukan secara bebas, dimana peniliti tidak perlu pedoman wawancara yang disusun secara sistematis (Sugiyono, 2016). 3) dokumentasi, dokumen merupakan catatan peristiwa yang sudah berlalu (Sugiyono, 2013). Dalam penelitian ini dokumentasi digunakan untuk melengkapi data yang diperoleh dari segala kejadian dan kegiatan penting dalam penelitian mulai observasi, wawancara dan lainnya agar lebih dapat dipercaya untuk menjadi sumber data pendukung dari data yang diperoleh. Data didapatkan berupa catatan observasi, catatan wawancara, dokumentasi dan pendukung lainnya. Teknik analisis data yang digunakan adalah penyederhanaan data, penyajian data dan penarikan kesimpulan.

\section{HASIL DAN PEMBAHASAN}

Hasil

Salah satu faktor yang berkaitan dengan kualitas tumbuh kembang anak adalah pengaruh teknologi. Berdasarkan laporan terbaru Hootsuite dan We Are Social, hingga januari 2021 penggunaan internet Indonesia meningkat hingga mencapai 202,6 juta. Dibandingkan dengan jumlah penggunaan internet pada tahun 2020 , terdapat kenaikan $15,5 \%$ atau lebih dari 27 juta pengguna internet di Indonesia dalam 12 bulan terakhir. Persentase penggunaan internet berusia 16 hingga 64 tahun yang memiliki masing-masing jenis perangkat, di antaranya mobilephone $(98,3 \%)$, smartphone $(98,2 \%)$, nonsmartphone 
mobile phone (16\%), laptop atau komputer desktop (74,7\%), tablet (18,5\%), TV streaming (6\%), konsol game $(16,2 \%)$, hingga virtual reality device $(4,2 \%)$. Dalam laporan ini juga diketahui bahwa saat ini masyarakat Indonesia yang memiliki ponsel sebanyak 338,2 juta. Begitu juga data yang tak kalah menariknya, terdapat 170 juta pengguna aktif media sosial

Penggunaan gadget tidak pernah terlepas dari pengaruh positif dan negatif. Orang tua berperan penting dalam pendidikan anak untuk menjadikan generasi muda yang dapat meraih keberhasilan di masa yang akan datang. Orang tua juga mempunyai tanggung jawab yang besar dalam memberikan bimbingan kepada anak - anaknya. Peran orang tua sangatlah penting bagi pendidikan anak usia sekolah dasar pada saat pembelajaran daring saat ini (Fatmala, Bintoro, \& Ardianti, 2021; Yulianingsih, Suhanadji, Nugroho, \& Mustakim, 2020). Orangtua sebaiknya memberikan perhatian terhadap anak dalam belajar agar anak termotivasi untuk belajar sungguh - sungguh dan mendapatkan hasil belajar yang maksimal. Beberapa cara yang digunakan oleh orang tua agar anak tidak kecanduan dengan gadget yakni peran orang tua menjadi contoh yang baik bagi anak, tetapkan aturan waktu penggunaan gadget, tetapkan aplikasi apa saja yang bisa dipakai oleh anak, pengawasan orang tua ketika anak diberi gadget, imbangi pemakaian gadget dengan aktivitas yang lain, dan penggunaan gadget tidak boleh menggantikan peran orang tua sebagai guru utama bagi anak (Suryameng, 2019). Dalam penelitian yang dilakukan peneliti di Desa Soco Kecamatan Dawe Kabupaten Kudus, peneliti ingin mengetahui peran orang tua dalam mengontrol penggunaan gadget pada anak usia 11 tahun. Untuk itu peneliti sudah melakukan wawancara dan observasi dengan lima orang tua yang memiliki anak usia 11 tahun. Adapaun hasil penelitian yang diperoleh peneliti yaitu:

Pertama, Orang tua berperan dalam membatasi waktu penggunaan gadget. Orang tua mengizinkan anak untuk menggunakan gadget ketika anak kesulitan dalam mengerjakan tugas yang diberikan oleh guru selama pembelajaran daring. Membatasi anak menggunakan gadget untuk bermain yaitu hanya hanya mengizinkan anak bermain handphone, baik itu di dalam rumah maupun di luar rumah selama 1 jam lebih 30 menit. Setelah waktu bermain handphone habis, anak langsung mengembalikan handphonenya (Ebi, 2017; Edy, 2015). Hal ini sama dengan penelitian yang dilakukakan bahwa pemakaian gadget yang baik pada anak usia 6 - 18 tahun adalah 2 jam per hari karena jika menggunakan gadget secara berlebihan bisa menyebabkan anak - anak kehilangan waktu dan semangat untuk belajar ataupun bermain bersama teman - temannya. Peran orang tua dalam memberikan batasan waktu pada anak yakni memiliki tujuan akan tercapainya suatu pendidikan yang baik. Jika anak mendapatkan batasan waktu yang baik dari orang tua dan anak mau mengikutinya, dapat menjauhkan anak dari dampak negatif penggunaan gadget misalnya kecanduan. Anak juga dapat berhasil dalam pendidikan dan mendapatkan prestasi yang baik.

Namun dalam hasil wawancara juga terdapat orang tua yang kurang berperan dalam mengontrol penggunaan gadget pada anak dikarenakan kesibukan dalam bekerja. Peran orang tua dalam memberikan batasan waktu dalam menggunakan gadget tidak ada. Jika orang tua sibuk bekerja handphone memang sudah menjadi pegangannya. Orang tua sudah mempercayakan sepenuhnya pada anak. Hal tersebut dapat menyebabkan anak terkena dampak negatif gadget. Meskipun sibuk dengan pekerjaan alangkah baiknya jika orang tua tetap berusaha memberikan batasan waktu agar anak bisa disiplin dalam memanfaat gadget. Anak juga tau kapan waktu ia bermain, belajar ataupun membantu orang tua (Kurniati, Nur Alfaeni, \& Andriani, 2020; Sahriana, 2019).

Kedua, Selektif dalam memilihkan aplikasi. Orang tua telah berusaha menyarankan anak untuk lebih mengakses fitur-fitur atau situs yang dapat mendukung dalam pembeljaran daring. Diharapkan anak tidak kecanduan dengan aplikasi yang telah diakses. Jika selektif memilihkan aplikasi, maka hal-hal yang diterima anak adalah hal yang positif. Diperkuat dengan hasil penelitian (Chusna, 2017a) yakni semua permainan, sosial media, video itu semua harus melewati pengawasan orangtua. Sebab unsur kekerasan dan pornografi rentan terjadi atau mudah didapatkan pada konten tersebut. Orang tua juga harus menemani anaknya dalam penggunaan gadget. Sama dengan hasil penelitian yang dilakukan oleh (Roza, Kamayani, \& Gunawan, 2018) yakni orang tua harus memahami bahwa penggunaan gadget pada anak perlu selektif dalam memilihkan aplikasi yang dapat mendukung kecerdasan anak dan pola pikir anak.

Ketiga Menemani anak dalam penggunaan gadget. Peran orang tua dalam menemani atau mengawasi anak saat menggunakan gadget sangat diperlukan. Hal tersebut karena untuk melindungi anak dari mengakses hal - hal yang berbau negatif atau pornografi. Berdasarkan wawancara Ibu NH dengan MD peran Ibu NH dalam menemani anak bermain gadget sudah baik. Ibu NH memantau MD dengan batasan maksimal 2 jam saat bermain, bila waktu melebihi 2 jam mau tidak mau MD harus mengembalikan handphone kepada orang tua. Orang tua telah menjalankan perannya dengan baik. Mereka saling bergantian untuk mengawasi atau menemani anak-anaknya. Jika salah satu atau keduanya tidak sibuk, maka orang tua menyempatkan untuk menemani anak saat ia menggunakan gadget. Pernyataan tersebut 
juga diperkuat dengan penelitian yang dilakukan oleh (Abdulatif \& Lestari, 2021) menjelaskan bahwa pada masa pandemi seperti sekarang ini mengharuskan pengawasan yang sangat ekstra dari orang tua sangat dibutuhkan dan sangat diperlukan ketika proses pembelajaran di rumah saja. Jika anak terus diawasi ketika proses pembelajaran yang menggunakan gadget, maka anak akan menggunakan dengan baik. Namun sebaliknya, apabila tidak diawasi dan diperhatikan, maka gadget tersebut akan disalahgunakan, contohnya, mereka lebih tertarik bermain game. Orang tua juga harus menemani anaknya dalam penggunaan gadget. Terkait dengan hal tersebut, diperkuat oleh penelitian yang dilakukan (Zulfitria, 2017) dalam pola asuh orang tua dalam penggunaan smartphone pada anak sekolah dasar. Hasil penelitiannya menyimpulkan bahwa anak yang kurang mendapatkan informasi dan arahan dari orang tua mengenai penggunaan smartphone akan salah dalam memanfaatkan smartphone yang mereka miliki. Anak akan lupa waktu dalam melaksanakan kewajibannya sebagai pelajar dan akan berdampak pada penurunan prestasi belajarnya.

Keempat Melatih tanggung jawab penggunaan gadget. Anak sudah dibelikan orang tua sebuah gadget maka harus dapat bertanggung jawab atas pemakaiannya. Tanggung jawab sangat diperlukan agar anak tetap disiplin dan mengetahui aturan - aturan yang diberikan orang tua terhadap anak dalam enggunaan gadget. Contoh tanggung jawab yang diberikan orang tua kepada anak, menurut hasil wawancara dengan narasumber yaitu untuk membeli kouta anak dilatih mandiri dengan menyisihkan atau menabung sisa uang jajan, mengembalikan gadget tepat waktu, anak diperbolehkan menggunakan gadget apabila anak mau mengerjakan tugas rumah, menyapu dulu atau yang lain sebelum menggunakan gadget. Kalau tugas belum diselesaikan maka gadget tidak diberikan. Tanggung jawab anak dalam penggunaan gadget juga diperlukan dan sangat penting karena nantinya anak tidak seenaknya dalam menggunakan gadget. Bagi orang tua yang belum melatih anak bertanggung jawab dalam penggunaan gadget sebaiknya perlu melatihnya dengan tegas agar anak bisa disiplin dan bijak dalam memakai gadget.

Kelima Berinteraksi sosial. Ketika anak sudah asik dengan gadgetnya, maka seringkali mengabaikan interaksi dengan lingkungan sekitar. Orang tua berusaha mengontrol anak dalam penggunaan gadget, yakni dengan memberikan tindakan pada anak jika dalam berinteraksi dengan keluarga, teman, atau orang di lingkungan sekitar kurang baik karena terlalu asik dengan handphone nya. Misalnya, orang tua memberikan teguran kepada anaknya agar berhenti main handphone. Hal ini sejalan dengan penelitian (Witarsa, 2018) yakni penggunaan gadget pada siswa SD dapat mengurangi interaksi sosialnya dalam kehidupan sehari-hari, baik dengan orang tuanya, teman sebayanya, maupun dengan masyarakat. Untuk itu, ada baiknya orang tua perlu mendampingi dan membimbing anaknya saat sedang menggunakan gadget. Oleh karena itu, peran orang tua tetap mengajak anak berinteraksi sosial sangat diperlukan. Melalui peran tersebut orang tua dapat mengontrol anak dalam penggunaan gadget dengan baik, terutama pada anak usia 11 tahun.

\section{Pembahasan}

\section{Dampak Positif Penggunaan Gadget}

Gadget memberikan dampak positif bagi anak apalagi dalam pembelajaran secara daring / online / jarak jauh akibat pandemi covid-19 ini yang mewajibkan anak agar belajar di rumah karena diberlakukannya lockdown atau physical distancing (Harsela \& Qalbi, 2020; Suhana, 2018). Dampak positif dari penggunaan gadget yang terjadi pada anak-anak sebagai berikut. 1) menambah pengetahuan. Dengan menggunakan gadget anak dapat mencari informasi melalui internet, seperti menonton video pembelajaran di youtube dan mencari materi di google sehingga anak mampu menyelesaikan tugas dari sekolah (Husaini, 2019; Purwanto et al., 2020), 2) memperluas jaringan persahabatan. Dengan menggunakan gadget bisa anak dapat memperluas jaringan persabatan melalui bermain game bersama, 3) mempermudah komunikasi. Gadget dapat memudahkan orang tua, keluarga, anak untuk berkomunikasi dan sangat berperan penting dalam pembelajaran di masa pandemic. Hal tersebut sejalan dengan pendapat (Alia \& Irwansyah, 2018) yakni beberapa hal yang menjadi dampak positif dalam penggunaan gadget bagi anak adalah dapat menambah wawasan, anak dapat membangun relasi atau memperbanyak teman tanpa harus dibatasi jarak dan waktu. Dalam hal pengetahuan anak dapat dengan mudah mengakses atau mencari situs tentang pengetahuan dengan mengoperasikan aplikasi yang ada dalam gadget contohnya aplikasi google atau youtube. Gadget juga dapat mempermudah komunikasi dengan orang lain maupun keluarga yang berada jauh dari kita dengan cara sms, telepon, ataupun WhatsApp (Chusna, 2017a). Untuk itu, penggunaan gadget akan memberikan dampak bagi penggunanya.

\section{Dampak Negatif Gadget pada Anak}

Walaupun gadget mempunyai dampak positif yang besar khusunya dalam bidang pendidikan dan komunikasi, namun penggunaan gadget yang berlebihan bagi anak juga menimbulkan beberapa dampak negatif (Subarkah, 2019; Syifa, Setianingsih, \& Sulianto, 2019). Pada saat anak memasuki usia sekolah 
dasar yaitu umur 6 - 12 tahun, perkembangan anak akan sangat cepat, baik perkembangan secara fisik maupun perkembangan secara psikologis. Pada umur ini anak juga memiliki rasa penasaran yang tinggi. Gadget sangat berpengaruh terhadap perkembangan anak. Gadget membawa dampak negative dan positif terhadap anak. Berdasarkan pendapat orang tua di Desa Soco Kecamatan Dawe Kabupaten Kudus mengenai dampak negatif penggunaan gadget yang dialami oleh anak yakni 1) anak mengabaikan perintah orang tua, 2) menyebabkan kecanduan, serta 3) konsentrasi belajar anak yang menurun. Hal tersebut sejalan dengan pendapat yang mengungkapkan bahwa dampak negatif penggunaan gadget yakni anak cenderung memiliki ketergantungan pada gadget dan juga penurunan konsentrasi saat belajar (Harsela \& Qalbi, 2020; Saputri \& Pambudi, 2018).

Sosok yang paling berpengaruh dalam mencegah atau mengatasi dampak negatif penggunaan gadget adalah orang tua. Pendampingan dialogis dari orang tua sangat dibutuhkan dalam mengurangi dampak negatif penggunaan gadget (Ariston \& Frahasini, 2018; Yanizon, Rofiqah, \& Ramdani., 2019). Orang tua menjadi pendamping dan pengawas nomor satu yang tidak dapat digantikan perannya dalam mendidik anak. Orang tua juga wajib bertanggung jawab dalam mengatasi dampak negatif dari penggunaan gadget. Beberapa cara yang harus dilakukan orang tua dalam mengawasi anak ketika menggunakan gadget adalah sebagaia berikut. (1) Batasi waktu anak. Ketika anak masuk usia praremaja, orang tua bisa memberi kebebasan yang lebih karena anak usia ini juga perlu gadget untuk fungsi jaringan sosial mereka. Di atas usia 5 tahun (mulai 6 tahun sampai usia 12 tahun) orang tua bisa memperbanyak waktu anak bergaul dengan gadge., Jika orang tua telah menerapkan kedisiplinan dari awal, maka di usia praremaja anak akan bisa menggunakan gadget secara bertanggung jawab (Mulyani, Masrul, \& Astuti, 2021; Sahriana, 2019), (2) Hindarkan kecanduan. Kecanduan atau penyalahgunaan gadget biasanya terjadi karena orang tua tidak mengontrol penggunaannya saat anak masih kecil, maka sampai remaja pun ia akan melakukan cara pembelajaran yang sama. Orang tua harus menerapkan aturan kepada anak tanpa bersikap otoriter, (3) Beradaptasi dengan zaman. Dampak positif gadget akan membantu perkembangan fungsi adaptif seorang anak. Artinya, seorang anak harus tahu fungsi gadget dan harus bisa menggunakannya karena salah satu fungsi adaptif manusia zaman sekarang adalah harus mampu mengikuti perkembangan teknologi. Hal lain yang dapat dilakukan oleh orang tua adalah mengajak anak melakukan kegiatan positif, seperti berolahraga bersama, berkebun, ataupu membuatu kerajinan dari bahan-bahan yang mudah ditemukan, sehingga anak-anak memiliki kesibukan lain dan tidak fokus terhadap kehadian gadget (P. A. S. C. Dewi \& Khotimah, 2020; Hadi, 2020). Orang tua diharapkan lebih komunikatif anak, bertanya tentang kesulitan yang dihadapi, sehingga anak merasa diperhatikan dan disayang. Selain itu, orangtua berusaha membangun suasana lingkungan yang kondusif. Orang tua harus mampu menciptakan suasana belajar yang menyenangkan untuk siswa sehingga mereka dapat belajar dengan baik (Astuti, Sunarno, \& Sudarisman, 2012; Iftitah \& Anawaty, 2020). Oleh karena pentingnya peran orang tua dalam mengawasi anak saat menggunakan gadget, maka diharapkan orang tua mau lebih peduli terhadap perkembangan anak dengan meluangkan waktu untuk membantu anak belajar, berdiskusi, bertanya, dan sangat penting adalah orang tua memberikan semangat kepada anak. Semangat tersebut dapat berupa kata-kata yang menimbulkan dorongan dalam diri anak. sebagai media untuk pemacu semangat anak.

\section{SIMPULAN}

Dari hasil penelitian yang telah dilaksanakan dapat disimpulkan mengenai peran orang tua dalam mengontrol penggunaan gadget pada anak usia 11 tahun. Orang tua dapat memberikan batasan waktu penggunaan gadget, selektif dalam memilihkan aplikasi untuk anak, menemani anak saat menggunakan gadget, melatih anak untuk bertanggung jawab atas penggunaan gadget, dan orang tua berusaha mengawasi anak dalam berinteraksi sosial dengan baik. Orang tua telah berusaha dengan baik untuk melaksanakan peran tersebut. Orang tua berharap dengan sistem pembelajaran daring/online/dari rumah, anak - anak tetap bertanggung jawab dalam pendidikan agar bisa berprestasi dengan baik. Dengan pengawasan dari orang tua, anak lebih menerima banyak hal-hal positif dan terhindar dari dampak negatif penggunaan gadget. Dampak positif yang terjadi pada anak usia 11 tahun yakni dapat menambah pengetahuan, memperluas jaringan persahabatan, dan mempermudah komunikasi. Sedangkan dampak negatif yang terjadi pada anak usia 11 tahun yakni anak mengabaikan perintah orang tua, terjadi kecanduan, serta konsentrasi belajar yang menurun. Akan lebih baik jika orang tua berusaha mendampingi anaknya yang sedang menggunakan gadget. Hal ini bertujuan agar anak ketika melakukan pembelajaran daring tidak mengakses aplikasi lain dan bisa fokus dengan pembelajarannya. Terutama bagi anak usia 11 tahun yang memiliki rasa ingin tahu yang tinggi agar diarahaan menggunakan gadget dalam kegiatan-kegiatan yang dapat mengasah kreatifvtas mereka dan terhindar dari situs yang negatif. 


\section{DAFTAR RUJUKAN}

Abdulatif, S., \& Lestari, T. (2021). Pengaruh Gadget terhadap Perkembangan Sosial Anak di Masa Pandemi. Jurnal Pendidikan Tambusai, 5(1), 1490-1493. Retrieved from https://jptam.org/index.php/jptam/article/download/1125/1007.

Alia, T., \& Irwansyah. (2018). Pendampingan Orang Tua pada Anak Usia Dini dalam Penggunaan Teknologi Digital. A Journal of Language, Literature, Culture, and Education POLYGLOT, 14(1), 65-78. https://doi.org/10.19166/pji.v14i1.639.

Anggraeni, S. (2019). Pengaruh Pengetahuan tentang Dampak Gadget bagi Kesehatan terhadap Perilaku Penggunaan Gadget pada Siswa SDN Kebun Bunga 6 Banjarmasin,". Faletehan Health Journal, 6(2), 65. Retrieved from https://journal.lppm-stikesfa.ac.id/index.php/FHJ/article/view/68/29.

Ariston, Y., \& Frahasini, F. (2018). Dampak Penggunaan Gadget bagi Perkembangan Sosial Anak Sekolah Dasar. Journal of Educational Review and Research, 1(2), 86-91. https://doi.org/10.26737/jerr.v1i2.1675.

Arwansyah, A., \& Wahyuni, S. (2020). Pengaruh Penggunaan Smartphone dan Minat Belajar terhadap Prestasi Belajar Siswa pada Mata Pelajaran Kewirausahaan SMK Al-Wasliyah Pasar Senen Medan TA 2018/2019. Jurnal Ekodik: Ekonomi Pendidikan, 7(1), 31-44. https://jurnal.unimed.ac.id/2012/index.php/ekodik/article/view/16446/12740.

Asmuni. (2020). Problematika Pembelajaran Daring di Masa Pandemi Covid-19 dan Solusi Pemecahannya. Jurnal Paedagogy: Jurnal Penelitian Dan Pengembangan Pendidikan, 7(4), 281-288.

Astuti, R., Sunarno, W., \& Sudarisman, S. (2012). Pembelajaran IPA dengan Pendekatan Keterampilan Proses Sains Menggunakan Metode Eksperimen Bebas Termodifikasi dan Eksperimen Terbimbing Ditinjau dari Sikap Ilmiah dan Motivasi Belajar Siswa. Universitas Sebelas Maret. Retrieved from http://jurnal.pasca.uns.ac.id.

Azizul, A., Riski, W. Y., Fitriyani, D. I., \& Sari, I. N. (2020). Pengembangan Bahan Ajar Komik Digital pada Mater Gerak. Vox Edokasi: Jurnal Ilmiah Ilmu Pendidikan, 11(2). https://doi.org/10.31932/ve.v11i2.829.

Chusna, P. A. (2017a). "Pengaruh Media Gadget pada Perkembangan Karakter Anak." Dinamika Penelitian: Media Komunikasi Sosial Keagamaan., $17(2), \quad 315 \quad$ - 329. https://doi.org/10.21274/dinamika.2017.17.2.315-330.

Chusna, P. A. (2017b). Pengaruh Media Gadget pada Perkembangan Karakter Anak. Dinamika Penelitian: $\begin{array}{lllll}\text { Media Komunikasi } & \text { Sosial Keagamaan, } & 17(2), & \end{array}$ https://doi.org/10.21274/dinamika.2017.17.2.315-330.

Dahlia, T., Safiah, I., \& Z., S. (2017). Pengaruh Penggunaan Handphone terhadap Perkembangan Karakter Anak pada Usia Sekolah Dasar di SDN 20 Kota Banda Aceh. Jurnal Ilmiah Pendidikan Guru Sekolah Dasar., 2(4), 143 - 149. Retrieved from http://www.jim.unsyiah.ac.id/pgsd/article/view/7748.

Damayanti, E., Ahmad, A., \& Bara, A. (2020). Dampak Negatif Penggunaan Gadget Berdasarkan Aspek Perkembangan Anak di Sorowako. Martabat J. Peremp. Dan Anak, 4(1), 1-22. http://ejournal.iaintulungagung.ac.id/index.php/martabat/article/view/2948.

Dewi, E. (2019). Potret Pendidikan di Era Globalisasi Teknosentrisme dan Proses Dehumanisasi. Sukma: Jurnal Pendidikan, 3(1), 93-116. https://doi.org/10.32533/03105.2019.

Dewi, P. A. S. C., \& Khotimah, H. (2020). Pola Asuh Orang Tua pada Anak di Masa Pandemi Covid-19. Seminar Nasional Sistem Informasi, 2433-2441. https://jurnalfti.unmer.ac.id/index.php/senasif/article/view/324.

Ebi, S. (2017). Golden age Parenting. Yogyakarta: Psikologi Corner.

Edy, A. (2015). Ayah Edy Menjawab Problematika Orangtua ABG dan Remaja. Jakarta: Noura Book Publising.

Fatmala, S., Bintoro, H. S., \& Ardianti, S. D. (2021). "Analisi Perhatian Orang Tua selama Pembelajaran Daring terhadap Kemampuan Pemahaman Matematis Siswa." Jurnal Ilmiah Bina Edukasi, 14(1), 1-10. https://doi.org/10.33557/jedukasi.v14i1.1365.

Hadi, L. (2020). Persepsi Mahasiswa terhadap Pembelajaran Daring di Masa Pandemik Covid-19 Student Perceptions of Online Learning During Covid-19 Pandemic. Jurnal Zarah, 8(2), 56-61. https://doi.org/10.31629/zarah.v8i2.2464.

Harsela, F., \& Qalbi, Z. (2020). “Dampak Permainan Gadget dalam Memengaruhi Perkembangan Kognitif Anak di TK Dharma Wanita Bengkulu." Jurnal Pena Paud, 1(1), 27 - 39. https://doi.org/10.33369/penapaud.v1i1.13851.

Hudaya, A. (2018). Pengaruh Gadget terhadap Sikap Disiplin dan Minat Belajar Peserta Didik. Research and Development Journal of Education, 4(2). https://doi.org/10.30998/rdje.v4i2.3380

Husaini, M. (2019). Pemanfaatan Teknologi Informasi dalam Bidang Pendidikan (E-education). JURNAL MIKROTIK, 2(1). https://doi.org/10.31219/osf.io/ycfa2 
Husaini, M., \& Lampung, I. R. I. (2014). Pemanfaatan Teknologi Informasi dalam Bidang Pendidikan (EEducation). MURNAL MIKROTIK, 2(1). Retrieved from https://ojs.ummetro.ac.id/index.php/mikrotik/article/view/314.

Iftitah, S. L., \& Anawaty, M. F. (2020). Peran Orang Tua dalam Mendampingi Anak di Rumah Selama Pandemi Covid-19. JCE (Journal of Childhood Education), 4(2), $71 \quad$ - 81. https://doi.org/10.30736/jce.v4i2.256.

Imron, R. (2017). Hubungan Penggunaan Gadget dengan Perkembangan Sosial dan Emosional Anak Prasekolah di Kabupaten Lampung Selatan. Jurnal Keperawatan, 13(2), 151. Retrieved from http://www.ejurnal.poltekkes-tjk.ac.id/index.php/JKEP/article/view/922/700.

Karwati, L., Kurniawan, D., \& Anggraeni, R. (2020). Pendampingan Orangtua pada Anak Pengguna Gawai di Satuan Pendidikan Anak Usia Dini. Jurnal Ilmiah Visi, 15(1), 33-40. https://doi.org/10.21009/JIV.1501.4.

Kumala, A. M., Ani Margawati, \& Rahadiyanti, A. (2019). Hubungan antara Durasi Penggunaan Alat Elektronik (Gadget), Aktivitas Fisik, Pola Makan dan Status Gizi pada Remaja Usia 13-15 Tahun. Journal of Nutrition College, 8(2), 73-80. https: //doi.org/10.14710/jnc.v8i2.23816.

Kurniati, E., Nur Alfaeni, D. K., \& Andriani, F. (2020). Analisis Peran Orang Tua dalam Mendampingi Anak di Masa Pandemi Covid-19. Jurnal Obsesi: Jurnal Pendidikan Anak Usia Dini, 5(1), 241. https://doi.org/10.31004/obsesi.v5i1.541.

Kusumantara, K. S., Santyadiputra, G. S., \& Sugihartini, N. (2017). Pengaruh E-Learning Schoology terhadap Hasil Belajar Simulasi Digital dengan Model Pembelajaran SAVI. Jurnal Pendidikan Teknologi Dan Kejuruan, 14(2), 126-135. https://doi.org/10.23887/jptk-undiksha.v14i2.10387.

Lestari, S. (2018). Peran Teknologi Dalam Pendidikan di Era Globalisasi. Edureligia, 2(2), 94-100.

Mulyani, E. R., Masrul, \& Astuti. (2021). Analisis Perhatian Orang Tua terhadap Minat Belajar Siswa Kelas IV Sekolah Dasar pada Masa Pandemi Covid 19. Jurnal Pendidikan Tambusai, 5(2), 261-266. https://jptam.org/index.php/jptam/article/view/942.

Murni. (2017). Perkembangan Fisik, Kognitif, Dan Psikososial pada Masa Kanak-Kanak Awal 2-6 Tahun. Jurnal Pendidikan Anak, 3(1), 19-33. https://jurnal.arraniry.ac.id/index.php/bunayya/article/view/2042.

Novitasari, W., \& Khotimah, N. (2016). Dampak Penggunaan Gadget terhadap Interksi Sosial Anak Usia 5-6 Tahun. Jurnal PAUD Teratai, 5(3), 182. Retrieved from https://jurnalmahasiswa.unesa.ac.id/index.php/paud-teratai/article/view/17261/15693\%0A.

Nurhalipah, R., Yustiana, M., Saeni, S., \& Muslih, M. (2020). Pengaruh Gadget terhadap Minat Belajar pada Anak-Anak. Seminar Nasional Informatika (SEMNASIF), 1(1), 172-177. http://jurnal.upnyk.ac.id/index.php/semnasif/article/view/4098.

Patricia, A. (2020). College Students' Use and Acceptance of Emergency Online Learning Due to COVID-19. International Journal of Educational Research Open, 100011. https://doi.org/10.1016/j.ijedro.2020.100011.

Pebriana, P. H. (2017). Analisis Penggunaan Gadget terhadap Kemampuan Interaksi Sosial pada Anak Usia Dini. Jurnal Obsesi: Jurnal Pendidikan Anak Usia Dini, 1(1), 1-11. https://doi.org/10.31004/obsesi.v1i1.26.

Pujilestari, Y. (2020). Dampak Positif Pembelajaran Online dalam Sistem Pendidikan Indonesia Pasca $\begin{array}{llll}\text { Pandemi Covid-19. Adalah, 4(1), 49-56. } & \end{array}$ http://journal.uinjkt.ac.id/index.php/adalah/article/view/15394.

Purwanto, A., Pramono, R., Asbari, M., Santoso, P. B., Wijayanti, L. M., Choi, C. H., \& Putri, R. S. (2020). Studi Eksploratif Dampak Pandemi COVID-19 terhadap Proses Pembelajaran Online di Sekolah Dasar. EduPsyCouns: Journal of Education, Psychology and Counseling, 2(1), 1-12. https://ummaspul.ejournal.id/Edupsycouns/article/view/397.

Putriana, K., Pratiwi, E. A., \& Wasliah, I. (2019). Hubungan Durasi dan Intensitas Penggunaan Gadget dengan Perkembangan Personal Sosial Anak Usia Prasekolah (3-5 Tahun) di TK Cendikia Desa Lingsar Tahun 2019. Jurnal Kesehatan Qamarul Huda, 7(2), 5-13. https://doi.org/10.37824/jkqh.v7i2.2019.112.

Rikizaputra, R., \& Sulastri, H. (2020). Pengaruh E-Learning dengan Google Classroom terhadap Hasil dan Motivasi Belajar Biologi Siswa. Lectura: Jurnal Pendidikan, 11(1), 106-118. https://doi.org/10.31849/lectura.v11i1.3760.

Rini, N. M., Pratiwi, I. A., \& Ahsin, M. N. (2021). Dampak Penggunaan Gadget terhadap Perilaku Sosial Anak Usia Sekolah Dasar. Jurnal Educatio, 7(3), 1236-1241. https://doi.org/10.31949/educatio.v7i3.1379.

Roza, E., Kamayani, M., \& Gunawan. (2018). Pelatihan Mmemantau Penggunaan Gadget pada Anak. Jurnal SOLMA., 7(2), 208 - 214. https://doi.org/10.29405/solma.v7i2.1062. 
Sahriana, N. (2019). Pentingnya Peran Orang Tua dalam Penggunaan Gadget pada Anak Usia Dini. Jurnal Smart PAUD, 2(1), 60-66. Retrieved from http://ojs.uho.ac.id/index.php/smartpaud/article/view/5922/pdf.

Saputri, A. D., \& Pambudi, D. A. (2018). Dampak Penggunaan Gadget terhadap Kemampuan Intraksi Sosial Anak Usia Dini. Adek Diah Saputri, Adek Diah Saputri, Diah Ayuning Pambudi, 3(265-278). Retrieved from http://ejournal.uin-suka.ac.id/tarbiyah/conference/index.php/aciece/aciece3.

Subarkah, M. A. (2019). Pengaruh Gadget terhadap Perkembangan Anak. Rausyan Fikr : Jurnal Pemikiran Dan Pencerahan, 15(1). https://doi.org/10.31000/rf.v15i1.1374.

Sugiyono. (2013). Metode Penelitian Kombinasi (Mixed Methods). Alfabeta. Bandung: Alfabeta, cv. https: //doi.org/10.1016/S0969-4765(04)00066-9.

Sugiyono. (2016). Metode Penelitian Kualitatif, Kuantitatif, dan R\&D. Bandung: Alfabeta.

Suhana, M. (2018). Influence of Gadget Usage on Children's Social-Emotional Development (Vol. 169, pp. 224-227). https://doi.org/10.2991/icece-17.2018.58.

Suryameng. (2019). "Pendampingan Dialogis Orang Tua dalam Penggunaan Gadget pada Anak Usia Dini." Dunia Anak:Jurnal Pendidikan Anak Usia Dini., 2(2), $40 \quad$ - 49. https://doi.org/10.31932/jpaud.v2i2.764.

Syifa, L., Setianingsih, E. S., \& Sulianto, J. (2019). Dampak Penggunaan Gadget terhadap Perkembangan Psikologi pada Anak Sekolah Dasar. Jurnal Ilmiah Sekolah Dasar, 3(4). https: //doi.org/10.23887/jisd.v3i4.22310.

Witarsa, R. (2018). "Pengaruh Penggunaan Gadget terhadap Kemampuan Interaksi Sosial Siswa Sekolah Dasar,." PEDAGOGIK, 6(1), $12 . \quad$ Retrieved from http://jurnal.unismabekasi.ac.id/index.php/pedagogik/article/view/432/334.

Yanizon, A., Rofiqah, T., \& Ramdani. (2019). “Upaya Pencegahan Pengaruh Gadget pada Anak melalui Kegiatan Penyuluhan dan Sosialisasi Dampak Gadget kepada Ibu-Ibu Kelurahan Tanjung Uma”. Minda Baharu: Jurnal Pengabdian Masyarakat., 3(2), 121-132. https://doi.org/10.33373/jmb.v3i2.2065.

Yulianingsih, W., Suhanadji, S., Nugroho, R., \& Mustakim, M. (2020). Keterlibatan Orangt ua dalam Pendampingan Belajar Anak selama Masa Pandemi Covid-19. Jurnal Obsesi : Jurnal Pendidikan Anak Usia Dini, 5(2), 1138-1150. https://doi.org/10.31004/obsesi.v5i2.740.

Zulfitria. (2017). Pola Asuh Orang Tua dalam Penggunaan Smartphone pada Anak Sekolah Dasar. HOLISTIKA:Jurnal Ilmiah PGSD, 1(2), 95 - 102. Retrieved from https://jurnal.umj.ac.id/index.php/holistika/article/download/2502/2070. 